\title{
Tissue Proteomics for the Next Decade? Towards a Molecular Dimension in Histology
}

\author{
Rémi Longuespée, Maximilien Fléron, ${ }^{2}$ Charles Pottier, ${ }^{3}$ Florence Quesada-Calvo,, Marie-Alice Meuwis, ${ }^{4}$ \\ Dominique Baiwir, ${ }^{5}$ Nicolas Smargiasso, Gabriel Mazzucchelli, Marie-Claire De Pauw-Gillet, ${ }^{2}$ \\ Philippe Delvenne, ${ }^{3}$ and Edwin De Pauw ${ }^{1}$
}

\begin{abstract}
The concept of tissues appeared more than 200 years ago, since textures and attendant differences were described within the whole organism components. Instrumental developments in optics and biochemistry subsequently paved the way to transition from classical to molecular histology in order to decipher the molecular contexts associated with physiological or pathological development or function of a tissue. In 1941, Coons and colleagues performed the first systematic integrated examination of classical histology and biochemistry when his team localized pneumonia antigens in infected tissue sections. Most recently, in the early $21^{\text {st }}$ century, mass spectrometry (MS) has progressively become one of the most valuable tools to analyze biomolecular compounds. Currently, sampling methods, biochemical procedures, and MS instrumentations allow scientists to perform "in depth" analysis of the protein content of any type of tissue of interest. This article reviews the salient issues in proteomics analysis of tissues. We first outline technical and analytical considerations for sampling and biochemical processing of tissues and subsequently the instrumental possibilities for proteomics analysis such as shotgun proteomics in an anatomical context. Specific attention concerns formalin fixed and paraffin embedded (FFPE) tissues that are potential "gold mines" for histopathological investigations. In all, the matrix assisted laser desorption/ionization (MALDI) MS imaging, which allows for differential mapping of hundreds of compounds on a tissue section, is currently the most striking evidence of linkage and transition between "classical" and "molecular" histology. Tissue proteomics represents a veritable field of research and investment activity for modern biomarker discovery and development for the next decade.
\end{abstract}

\section{Introduction}

\section{A historical context for histology and diagnostics}

$\mathbf{R}$ ECENT DISCOVERIES IN THE FIELDS OF BIOLOGY and medicine took place thanks to developments of new instruments and tools to overcome limited understanding of human environment. Histology, one of the oldest biomedical sciences, has greatly benefited from these advances to decipher the molecular content of a given tissue.

In the middle of the 19th century, tissue fixation was improved with the use of formalin to obtain optimal preservation of tissue morphological structures. Thereafter, analysis of specific compounds of interest within tissue sections emerged using immunohistochemistry (IHC) techniques combined with classical microscopy. Furthermore, with the development of antigen retrieval (AR) procedures to "unlock" the methylene bridges between proteins, it was possible to use formalin fixed and paraffin embedded (FFPE) tissues for IHC studies.

Progressively, tissue analyses evolved towards the description of the whole molecular content of a given sample. Currently, mass spectrometry (MS) is the most versatile analytical tool for protein identification and has proven its great potential for biological and clinical applications. "Omics" fields, and especially proteomics, are of particular interest since they allow the analysis of a biomolecular picture associated with a given physiological or pathological state. Biochemical techniques were then adapted for an optimal extraction of several biocompounds classes from tissues of different natures. Sampling methods were also developed and improved for selection and exploration of tissues contents, ranging from an entire specimen, sliced in

\footnotetext{
${ }^{1}$ Mass Spectrometry Laboratory, GIGA-Research, Department of Chemistry; ${ }^{2}$ Mammalian Cell Culture Laboratory, GIGA-Research, Department of Biomedical and Preclinical Sciences, and ${ }^{3}$ Laboratory of Experimental Pathology, GIGA-Cancer, Department of Pathology; ${ }^{4}$ Hepato-Gastroenterology and Digestive Oncology Department, Liège University Hospital; and GIGA-R, ${ }^{5}$ GIGA Proteomic Facilities, University of Liège, Liège, Belgium.
} 
sections, only selected areas, or cell groups of interest on a specific slice. For example, laser capture microdissection (LCM) is used to select and isolate tissue areas of interest for further analysis. The developments of MS instrumentations have then definitively transformed the scientific scene, pushing back more and more detection and identification limits. Since a few decades, new approaches of analyses appeared, involving the use of tissue sections dropped on glass slides as starting material. Two types of analyses can then be applied on tissue sections: shotgun proteomics and the very promising MS imaging (MSI) using Matrix Assisted Laser Desorption/Ionization (MALDI) sources. Also known as "molecular histology," MSI is the most striking hyphen between histology and molecular analysis. In practice, this method allows visualization of the spatial distribution of proteins, peptides, drugs, or others analytes directly on tissue sections. This technique paved new ways of research, especially in the field of histopathology, since this approach appeared to be complementary to conventional histology.

As a first overview, Figure 1 illustrates the different aspects of analysis of tissue samples.
This publication reviews the key issues in the field of proteomics analysis of tissues. We first outline the technical and analytical considerations for sampling and biochemical processing of tissues and subsequently detail instrumental possibilities for tissue proteomics analysis. FFPE tissues that represent potential "gold mines" for histopathological investigations are carefully covered in this review.

\section{Immunohistochemistry}

\section{The first hyphen between histology and biochemistry}

The first link between classical histology and biochemistry was made by Coons et al. in 1941, when his team localized pneumonia antigens in infected tissue sections. This was achieved with the use of specific antibodies against these antigens, stained with a florescent protein (fluorescein) instead of traditional chemical reagents (Coons and Kaplan, 1950).

The next improvement was reached by other teams with the creation of different detection systems. At this time, the method sensitivity was low, the captured images intensities were poorly reproducible, and it was hardly usable on fresh

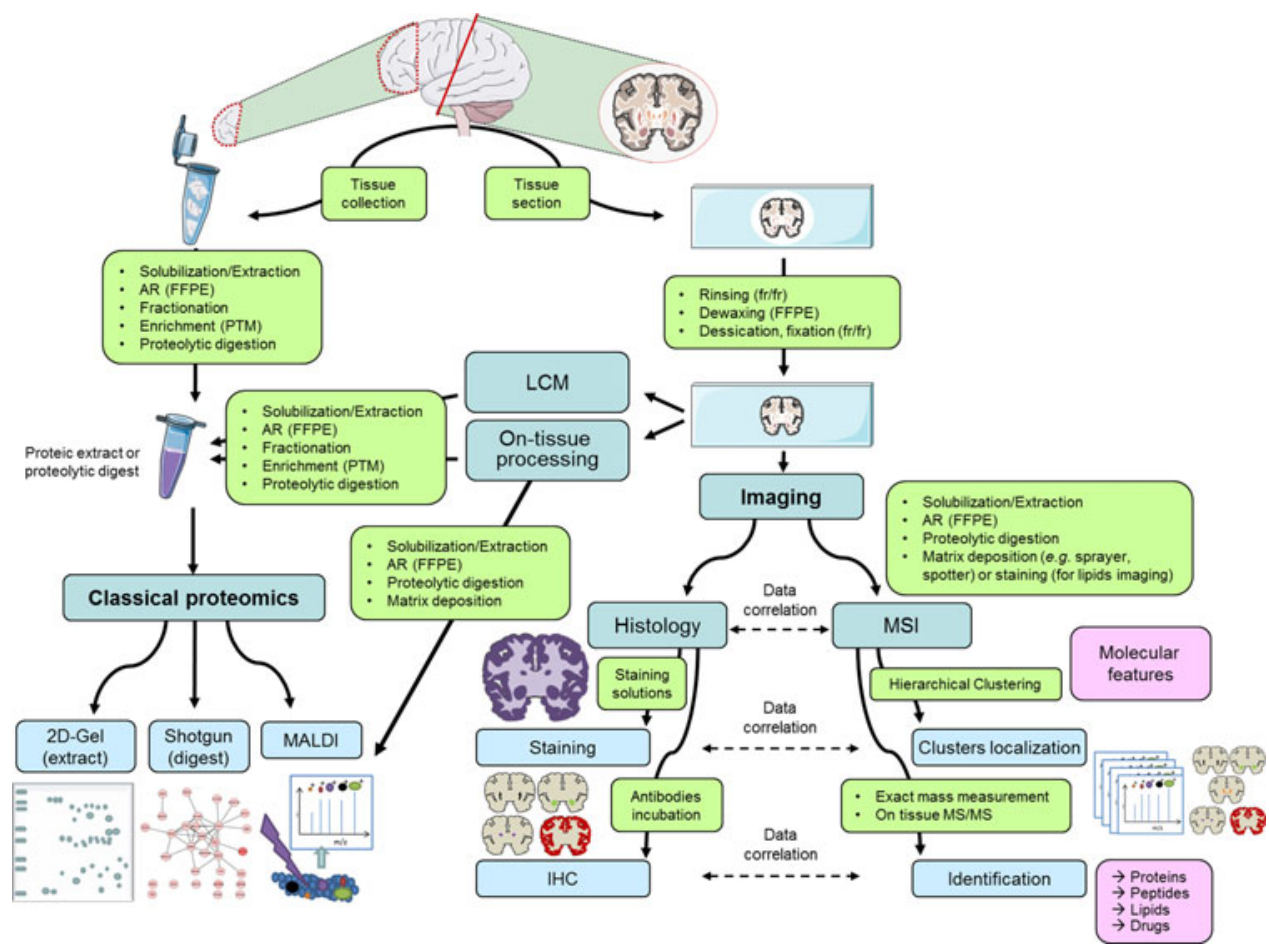

FIG. 1. Tissue processing workflows for molecular analyses. Tissues can either be processed in solution or directly on tissue sections. In solution, processing involves protein extraction from tissue pieces in order to perform 2D gel separation and identification of proteins, shotgun proteomics, or MALDI analyses. Extracts can also be obtained from tissues area selection and protein extraction after laser micro dissection or on-tissue processing. Imaging techniques are dedicated to the morphological characterization or molecular mapping of tissue sections. Histology can either be conducted by hematoxylin/eosin staining or by molecular mapping using antibodies with IHC. Finally, mass spectrometry imaging allows the cartography of numerous compounds in a single analysis. This approach is a modern form of "molecular histology" as it grafts, with the use of mathematical calculations, a molecular dimension to classical histology. (AR, antigen retrieval; FFPE, formalin fixed and paraffin embedded; fr/fr, fresh frozen; IHC, immunohistochemistry; LCM, laser capture microdissection; MALDI, matrix assisted laser desorption/ionization; MSI, mass spectrometry imaging; PTM, post translational modification.) 
frozen (fr/fr) tissues while maintaining their initial morphology. In order to overcome these limitations, Nakane and colleagues grafted enzymes (peroxidases) to antibodies to evaluate the presence of proteins on tissue sections. This method was based on the chemical reaction of the peroxidase enzyme grafted to the antibodies with a chromogen substrate to produce a colored product detectable by light microscopes (Nakane and Pierce, 1966). This improvement drastically impacted practices in use in worldwide histological laboratories (Avrameas and Uriel, 1966).

Soon after, it was possible to multiplex the detection of more than one protein in a tissue section (Nakane, 1968), thereby opening new possibilities in the field of histological biochemistry. Many chromogens were designed to react with the widely used horseradish peroxidase. It was therefore possible to visualize the presence of molecules using various compounds such as 3-amino-9-ethyl carbazole (AEC), which produces a red color, easily differentiable from classical hematoxylin staining. But the most used substrate is still the diaminobenzine molecule (DAB) which produces an electrodense precipitate, therefore also usable with electronic microscopy (Singer, 1959). In routine histopathological analyses, its brown color after osmification perfectly contrasts with many counterstains. Moreover, this color slowly fades, making processed tissue sections easy to use for long-term storage and available for further visualizations. The contrast of the histochemically treated images has then been amplified with the development of unlabeled antibodies in peroxidaseantiperoxidase (PAP) techniques (Sternberger et al., 1970) or the alkaline-anti-alkaline phosphatase method (Mason and Sammons, 1978). The method was proven to be efficient on the widely used FFPE tissues and became the reference technique in pathological laboratories (Leong and Wright, 1987; Nadji, 1986; Swanson, 1997).

\section{FFPE Tissues and Antigen Retrieval}

\section{Salient methods for large-scale applications}

Discovered in 1859, formalin was first proposed by the physician Ferdinand Blum for medical applications due to its disinfectant properties. During his work, he realized that tissues in contact with formalin became hardened, even more than with commonly used hardening agents. On this basis, contemporary histologists confirmed the unequaled properties of formalin as fixative agent, preserving tissue from shrinkage or distortion, in contrast to the widely used alcoholic agents. Moreover, the classical staining procedures using hematoxylin and eosin dyes totally matched with this fixation method and gave rise to excellent histological preparations. Since then, the formalin fixation procedure has become the golden technique for tissue fixation in histological practices. Combined with paraffin embedment, FFPE tissues were universally used in histo- and histopathological laboratories for long-term storage. FFPE tissues storage is possible at room temperature and thus easier than fr/fr tissues that need storage at $-80^{\circ} \mathrm{C}$. Other advantages of this conservation method are good architectural preservation of tissue structures and cellular shapes stabilization.

Formalin fixation is not a well-standardized method among laboratories; several criteria, such as fixation time, incubation temperature, or solution $\mathrm{pH}$ greatly affect the final properties of the tissue. Formalin reacts with proteins and peptides, inducing the formation of a methylol on lysine, arginine, and cysteine thiol residues which subsequently dehydrates and reacts by forming crosslinks with amino acids such as arginine, glutamine, tryptophan, histidine, asparagine, and tyrosine. This reaction finally results in the formation of methylene bridges between proteins (Magdeldin and Yamamoto, 2012). This reaction strongly alters the initial conformation of proteins and may mask some epitopes. This could thereby interfere with antibody recognition. Consequently, fixation time strongly affects further IHC efficiency. Routinely, tissues are fixed during 24 to 48 hours in $10 \%$ formalin solution at $\mathrm{pH} 7$ with phosphate salts and $10 \%$ methanol (which act as solution stabilizer) (Nirmalan et al., 2008).

In IHC, some methods were progressively developed in order to overcome the masking antigen limitations induced by the formalin fixation. Generally, the use of a specific antibody for IHC detection needs a given AR method. AR is an empirical method and its mechanism of action is still controversial. The oldest AR method is the use of enzymatic digestion with proteolytic enzymes such as proteinase $\mathrm{K}$, pronase, or many others such as trypsin, which is the most popular one. Unfortunately, a very limited range of antigens were retrievable with this method (Leong et al., 1988). Tissue heating was then proposed and showed great antigenicity properties for a wider range of markers. Many heating procedures are possible, such as immersion of the tissue sections in water or using heated plates, but the most efficient one was found to be the use of microwaves (Leong, 1996). Chemical studies in the 1940s previously described that AR solutions at high temperatures could disrupt the proteins crosslinks induced by formalin (Fraenkel-Conrat and Olcott, 1946, 1948a, b). In conclusion, the detection of many different antigens can be significantly improved either by the use of a pretreatment with an AR reagent (e.g., acid buffers or proteolytic methods) that breaks the protein crosslinks formed and thereby uncovers hidden antigenic sites, or by heating (higher than $80^{\circ} \mathrm{C}$ ) and/or using pressure, combined with immersions in buffers of different possible composition and $\mathrm{pH}$.

\section{FFPE Tissues and Proteomics}

\section{Optimal tissue solubilization towards protein extraction}

Proteome analysis of FFPE tissues presents some obstacles inherent to their nature and to the poor cross-linked protein solubility. In this section, we will focus on the use of FFPE tissues for proteomics studies, on the different sample handling improvements that have been made to allow differential proteomic applications, and on the biochemical procedures that permitted proper protein extractions with these specific tissues.

In 1998, as a first hyphen between IHC and proteomic fields, Ikeda et al. (1998) analyzed the effect of temperature and the efficiency of different buffers on protein extraction from FFPE tissue samples. Ikeda concluded that combination of both heat and lysis buffer like RIPA (radio immunoprecipitation assay) with a concentration of sodium dodecyl sulfate (SDS) of $2 \%$ provided the best protein concentration recovery. Since then, several researches were performed to improve extraction buffers and protein extraction efficiency. 
Numerous solutions were tested to perform protein extraction from FFPE tissues. The initial buffer is generally Tris $/ \mathrm{HCl}$ at different $\mathrm{pH}$ mostly associated with a panel of detergents and chaotropes. The composition of these solutions have recently been reviewed by Giusti et al. (Giusti and Lucacchini, 2013) and Maes et al. (2013). Amongst the used extraction solutions, Tris $50 \mathrm{mM}$ pH7 (Fowler et al., 2012) and Tris $20 \mathrm{mM} \mathrm{pH} 9$, both used with $2 \%$ SDS in combination with high pressure (Xu et al., 2008), enabled protein recoveries ranging from $17 \%$ to $95 \%$ compared to fr/fr tissues, on a liver sample. Reducing agents such as $\beta$-mercaptoethanol (Nirmalan et al., 2009) or dithiotreitol (DTT) can also be added to these solutions as performed on skeletal muscle or liver (Addis et al., 2009; Ostasiewicz et al., 2010), as well as heart tissues (Azimzadeh et al., 2010) using octylglucoside as detergent. Another possible detergent is guanidin- $\mathrm{HCl}$ (Jiang et al., 2007). Chaotropic agents can also be used for proteins retrieval from FFPE tissues (Guo et al., 2007). RIPA buffers were used with different amounts of $\mathrm{NaH}_{2} \mathrm{PO}_{4}, \mathrm{NaHPO}_{4}, \mathrm{NaCl}$, Triton, fluoride, sodium cholate, sodium azide, and ethylenediamine tetraacetic acid (EDTA) on colorectal carcinoma (Ikeda et al., 1998), lymphoma (Crockett et al., 2005), and prostate cancer specimens (Hwang et al., 2007). Organic solvents can also be employed at different concentrations as solubilizing agents such as $30 \%$ acetonitrile, which was applied on pancreatic (Pan et al., 2011) and colon cancer tissues (Kakimoto et al., 2012). 50\% trifluoroethanol (TFE) for lung tissue processing was also tested (Tian et al., 2009). Commercial solutions exist for FFPE tissue processing such as the acid-deteriorating detergent RapiGest (Nirmalan et al., 2011), Liquid Tissue MS protein Prep kit (Nakatani et al., 2012; Prieto et al., 2005), Qproteome FFPE tissue kit (Becker et al., 2007), NDME-U (Chu et al., 2005), and FFPE Protein Extraction Solution (Agilent Technologies, Santa Clara, CA). Moreover, all these treatments methods can be applied with a digestion step done on Microcon (Millipore, Billerica, MA) or Vivacon (Vivaproducts, Littleton, USA) units. This Filter Aided Sample Preparation (FASP) procedure was elaborated by Mann's team and consists in protein unfolding from FFPE tissues using diverse lysis solutions composed of detergents such as $4 \%$ SDS, chaotropes such as $8 \mathrm{M}$ urea, and reductive agents such as iodoacetamide. This filter system is particularly efficient to remove processing solutions and to rinse the samples; however it is important to ensure that the applied treatments cannot damage the employed filter. Subsequently, the protein digestion can be performed directly on the filter to recover the tryptic peptides that will be subjected to analysis after desalting (Wisniewski et al., 2011). This last procedure appears to be the most efficient method for proteomics studies on microdissected tissues and subsequent LC-MS/MS analyses (further described in this present review). It recently led, with the combination of sample fractionation methods, to reach 10,000 identified proteins (Wisniewski et al., 2013).

Among these different studies, researchers aimed to evaluate the extraction procedures efficiencies on FFPE tissues in comparison to fr/fr tissues. Indeed, the main concern about the use of these FFPE tissues is to apply a procedure that could give rise to the largest molecular information, compared to the one available using fr/fr tissues. Generally, $\mathrm{fr} / \mathrm{fr}$ tissues give a higher number of proteins compared to FFPE tissues (Giusti and Lucacchini, 2013), but some studies re- ported a better proteins identifications recovery with FFPE tissues (Nirmalan et al., 2011; Palmer-Toy et al., 2005; Shi et al., 2006). These comparisons highlight the importance of the chemical treatments for efficient FFPE tissue preparation.

\section{Analytical Methods}

Analysis of tissue proteomes has greatly evolved with separation methods and mass spectrometry instrumentation. The choice of the workflow strongly depends on whether a bottom-up or a top-down analysis has to be performed downstream. In-gel or off-gel proteomics principally differentiates proteomic workflows. The almost simultaneous discoveries of the MS ionization sources (Nobel Prize awarded) MALDI (Hillenkamp and Karas, 1990; Tanaka et al., 1988) and electrospray ionization (ESI) (Fenn et al., 1989) have paved the way for analysis of intact proteins and peptides. Separation methods such as two-dimension electrophoresis (2DE) (Fey and Larsen, 2001) and nanoscale reverse phase liquid chromatography (nanoRP-LC) (Deterding et al., 1991) lead to efficient preparation of proteins for respectively topdown and bottom-up strategies. A huge panel of developments was then achieved mostly for LC-MS based proteomics in order to improve ion fragmentation approaches and peptide identification throughput relying on database interrogation. Moreover, approaches were developed to analyze post translational modifications (PTM) such as phosphorylations (Ficarro et al., 2002; Oda et al., 2001; Zhou et al., 2001) or glycosylations (Zhang et al., 2003), proposing as well different quantification procedures. Regarding instrumentation, the most cutting edge improvements are the gain of mass accuracy for an optimal detection of the eluted peptides during LC-MS runs (Mann and Kelleher, 2008; Michalski et al., 2011) and the increase in scanning speed, for example with the use of Orbitrap analyzers (Hardman and Makarov, 2003; Makarov et al., 2006; Makarov et al., 2009; Olsen et al., 2009). Ion transfer efficiency was also drastically improved with the conception of ion funnels that homogenize the ion transmission capacities through $\mathrm{m} / \mathrm{z}$ ranges (Kelly et al., 2010; Kim et al., 2000; Page et al., 2006; Shaffer et al., 1998) or by performing electrospray ionization within low vacuum (Marginean et al., 2010; Page et al., 2008; Tang et al., 2011). Beside collision induced dissociation (CID) that is proposed for many applications (Li et al., 2009; Wells and McLuckey, 2005), new fragmentation methods were investigated, such as higher-energy collisional dissociation (HCD) especially for phosphoproteomic applications (Nagaraj et al., 2010), and electron transfer dissociation (ETD) and electron capture dissociation (ECD) that are suited for phospho- and glycoproteomics (An et al., 2009; Boersema et al., 2009; Wiesner et al., 2008). Methods for data-independent $\mathrm{MS}^{2}$ analysis based on peptide fragmentation in given $m / z$ windows without precursor selection neither information knowledge, also improves identification throughput (Panchaud et al., 2009; Venable et al., 2004), especially with the use of MS instruments with high resolution and high mass accuracy specifications (Panchaud et al., 2011). Gas fractionation methods such as ion mobility (IM) can also be used as a supplementary separation dimension which enable more efficient peptide identifications (Masselon et al., 2000; Shvartsburg et al., 2013; Shvartsburg et al., 2011).

Data analysis methods were also investigated for protein identification either on the basis of database search algorithm 
with software such as SEQUEST (Diament and Noble, 2011) or MASCOT (Hirosawa et al., 1993; Kocher et al., 2011), spectral library searches (Desiere et al., 2006; Jones et al., 2006; Lam et al., 2007; Vizcaino et al., 2009; Yates et al., 1998), de novo sequencing (Cox and Mann, 2009; Frank and Pevzner, 2005; Tabb et al., 2008; Zhang et al., 2012), or with hybrid strategies (Mann and Wilm, 1994; Tabb et al., 2003, 2007).

A quantitative aspect can be implemented to 2DE strategies with 2D-DIGE (2 dimension-difference gel electrophoresis) (Lilley and Friedman, 2004; May et al., 2012). LC-MS based quantitative methods such as label free quantification (Higgs et al., 2005; Neilson et al., 2011; Wang et al., 2006), spectral counting quantification (Neilson et al., 2011), intensity based quantification (Bondarenko et al., 2002; Christin et al., 2011), and also labeling techniques were developed for off-gel analyses. Labeling methods such as isobaric tag for relative and absolute quantification (iTRAQ) (Aggarwal et al., 2006; Chen et al., 2010; DeSouza et al., 2005; Garbis et al., 2008; Muraoka et al., 2012; Wang et al., 2012), and the recently developed isotope coded protein labeling coupled to immunoprecipitation (ICPL-IP) (Vogt et al., 2013), both relying on the labeling of the primary amino groups and lysine residues, were developed. Isotope coded affinity tag (ICAT) (DeSouza et al., 2005), that labels cysteine residues was also applied for tissue proteomics.

Finally, a selected reaction monitoring (SRM) (or multiple reaction monitoring (MRM)) method was developed for targeted quantification and validation of markers of interest (Calvo et al., 2011; Kiyonami et al., 2011; Muraoka et al., 2012; Narumi et al., 2012; Nishimura et al., 2010).

\section{Sampling Methods}

By definition, a tissue is a well-organized ensemble of specialized cells, functionally grouped together to share multiple molecular information in a physiological or pathological context. In order to study the different types of tissues, several methods are devoted to specific area sampling and depend on the desired size, such as macrodissection (Azimzadeh et al., 2010; Nazarian et al., 2008) or the more accurate needle microdissection (Craven et al.; Prieto et al., 2005). Finally, the most precise technique to select a specific cell group in a tissue section is LCM.

\section{Laser capture microdissection (LCM)}

The large diversity of tissue cell types must be taken into account during sampling. Indeed, incorporation of different cell types in the same sample could present advantages but also inconveniences. LCM allows for separation and isolation of cells from a complex tissue and may enable single cell type analysis and/or comparative analyses. On the other hand, a restrictive disadvantage of LCM is the time required for sample selection and collection, particularly when many different tissue areas are involved. Two LCM approaches exist to extract cell groups from a tissue. The first one consists of a plastic film adhesion to the tissue surface boundaries induced by the laser energy, followed by embedding and collection of this surface for further chemical handling and analysis. This mode was proposed by Molecular Devices (Bonner et al., 1997; Emmert-Buck et al., 1996; Nakamura et al., 2007; Pietersen et al., 2009). The second mode of microdissection relies on a laser ablation principle. The tissue section is dropped on a plastic membrane covering a glass slide. The preparation is then placed into a microscope equipped with a laser. A highly focused beam will then be guided by the user at the external limit of the area of interest. This area composed by the plastic membrane, and the tissue section will then be ejected from the glass slide and collected into a tube cap for further processing. This mode of microdissection is the most widely used due to its ease of handling and the large panels of devices proposed by constructors. Indeed, Leica microsystem proposed the Leica LMD system (Kolble, 2000), Molecular Machine and Industries, the MMI laser microdissection system Microcut, which was used in combination with IHC (Buckanovich et al., 2006), Applied Biosystems developed the Arcturus microdissection System, and Carl Zeiss patented P.A.L.M. MicroBeam technology (Braakman et al., 2011; Espina et al., 2006a; Espina et al., 2006b; Liu et al., 2012; Micke et al., 2005). LCM represents a very adequate link between classical histology and sampling methods for molecular analyses as it is a simple customized microscope. Indeed, optical lenses of different magnification can be used and the method is compatible with classical IHC (Buckanovich et al., 2006). Only the laser and the tube holder need to be added to the instrumentation. The tube holder can either be placed above or under the glass slide to collect the samples whether the collection is based on catapulting effect or both catapulting and gravity effects, respectively.

After microdissection, the tissue pieces can be processed for analyses using different available MS devices and strategies. The simplest one consists in the direct analysis of the protein profiles by MALDI-TOF-MS (MALDI-time of flightMS). The microdissected tissues are dropped on a MALDI target and directly covered by the MALDI matrix (PalmerToy et al., 2000; Xu et al., 2002). This approach was already used in order to classify breast cancer tumor types (Sanders et al., 2008), identify intestinal neoplasia protein biomarkers (Xu et al., 2009), and to determine differential profiles in glomerulosclerosis (Xu et al., 2005).

LCM samples can also be studied using 2D gel electrophoresis. Many clinical applications have been investigated by this method, including biomarker identification of breast cancer (Thakur et al., 2011; Zanni and Chan, 2011; Zhang et al., 2005), pancreatic ductal carcinoma (Shekouh et al., 2003), nasopharyngeal carcinoma (Cheng et al., 2008), hepatocellular carcinoma (Wong and Luk, 2012), and abdominal aortic aneurysms (Boytard et al., 2013). In this last study, Boytard and colleagues highlighted that CD68(+)MR(-) macrophages could contribute to aneurysmal pathology, on the basis of the analyses of 2DE separated proteins originated from different types of macrophages. 2D-DIGE was also used for the analysis of esophageal cancer (Hatakeyama et al., 2006; Zhou et al., 2002), prostate cancer (Skvortsov et al., 2011), lymph node metastasis of human lung squamous adenocarcinoma (Yao et al., 2009), colorectal cancer (Shi et al., 2011; Sugihara et al., 2013), and malignant pleural mesothelioma (Hosako et al., 2012).

Currently the most common proteomic approach for LCM tissue analysis is LC-MS/MS. Label free LC-MS approaches have been used to study several cancers like head and neck squamous cell carcinomas (Baker et al., 2005), esophageal cancer (Hatakeyama et al., 2006), dysplasic cervical cells 
(Gu et al., 2007), breast carcinoma tumors (Hill et al., 2011; Johann et al., 2009), tamoxifen-resistant breast cancer cells (Umar et al., 2009), ER + / - breast cancer cells (Rezaul et al., 2010), Barretts esophagus (Stingl et al., 2011), and ovarian endometrioid cancer (Alkhas et al., 2011). Different isotope labeling methods have been used in order to compare proteins expression. ICAT was first used to investigate proteomes of hepatocellular carcinoma ( $\mathrm{Li}$ et al., 2004; 2008). The $\mathrm{O}^{16} / \mathrm{O}^{18}$ isotopic labeling was then used for proteomic analysis of ductal carcinoma of the breast (Zang et al., 2004).

Microdissected tissue pieces can also be investigated after their status linked to markers of interest. This approach was named immune laser capture microdissection (iLCM), where IHC is performed (Fend et al., 2000; Tangrea et al., 2011) prior to LCM. It was used for multiple clinical applications such as proteomic studies of prolactin cells from pituitary adenoma (Liu et al., 2010) or CD24+/- cells from pancreatic adenocarcinoma, this marker being directly correlated to cancerous tumorigenesis, progression, and metastasis of pancreatic cancer (Zhu et al., 2013).
The size of the samples leads to the final number of identified proteins. Generally, a high number of cells is mandatory for efficient proteins extraction from microdissected samples. Currently, the lowest amount of collected cells for a relevant single analysis using fr/fr breast cancer tissues was 3000-4000 (Braakman et al., 2012; Liu et al., 2012; Umar et al., 2007). With a Q-Exactive (Thermo, Waltham) mass spectrometer coupled to LC, Braakman was able to identify up to 1800 proteins from 4000 cells. Processing of FFPE microdissected tissues of limited sizes still remains an issue which is being addressed by our team.

\section{Direct tissue analysis}

As mentioned in the previous section, LCM represents a valuable technique that enables the study of the molecular content of a specific group of cells and its comparison to another one in the same tissue section. However, the complexity of the tissue system relies on interactions between different cell groups in a given physiological and pathological

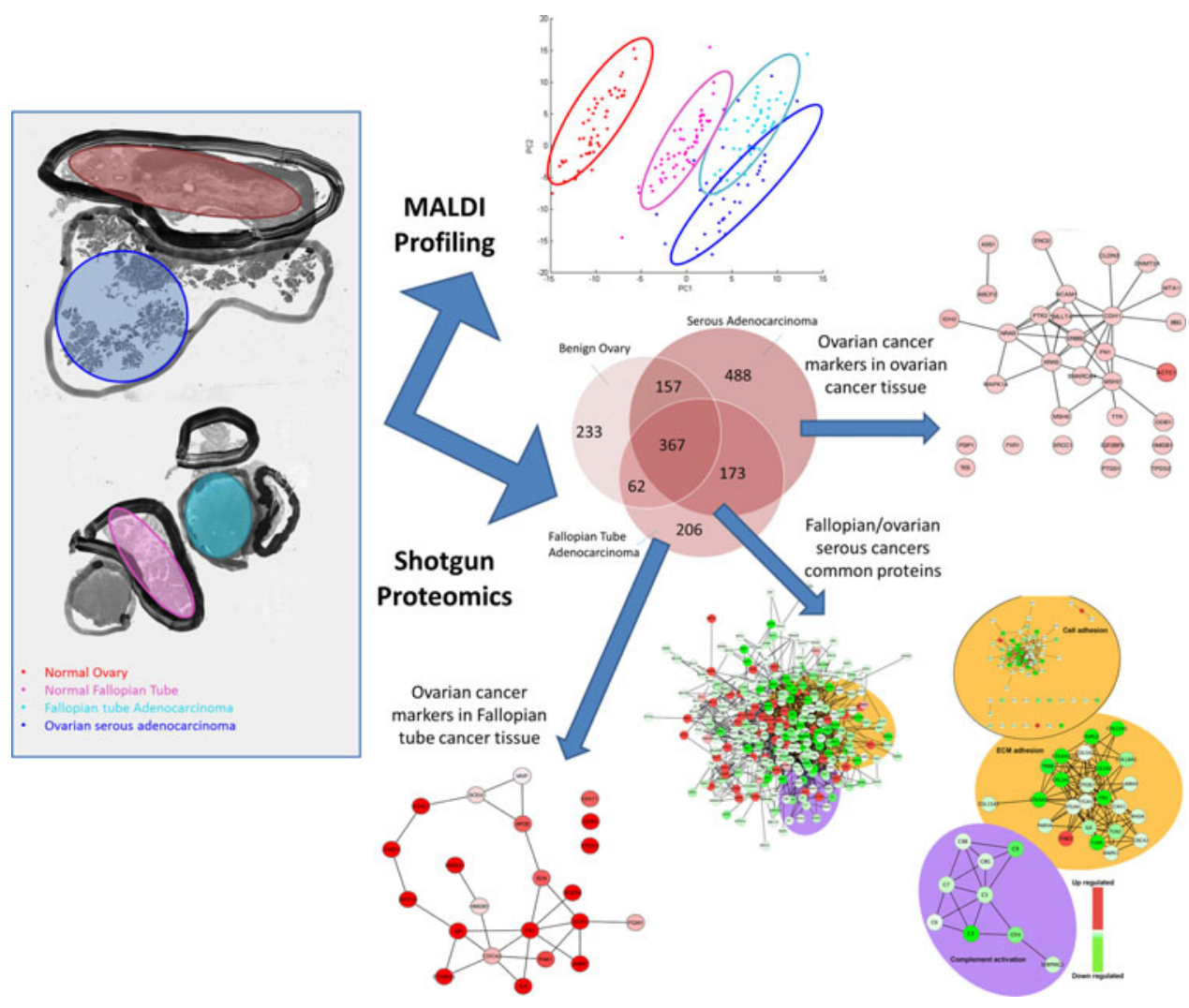

FIG. 2. On tissue processing workflow, application to ovarian cancer. In Longuespée et al. (2013), tissues from a single patient afflicted by serous ovarian cancer were selected. Selected patient also presents serous Fallopian tube cancer with serous tubal intraepithelial carcinoma (STIC), presuming the possible origin of ovarian cancer. A first MALDI analysis combined with PCA analyses was performed to evaluate the differential molecular features between the tissue types. In parallel, shotgun proteomics were performed to evaluate the molecular actors involved in a possible interaction between serous ovarian and tubal cancers. Among the detected proteins, some markers initially found to be ovarian cancer markers were here only detected in Fallopian tube cancer. Periostin, which is associated with metastatic processes, was found in tubal cancer, revealing that metastasis could occur in a pathological context. This study highlighted the high relevance to proceed to proteomic analyses in an anatomical context. This was also the first time that the "proteomic case study" concept was introduced. 
context. For example, in metastasis processes, nesting of detached spheroid-shaped cells groups from the primary tumor is strongly dependent to the hosting tissue cells content (Zhang et al., 2011). A molecular communication between these cells and the extracellular matrix is of first importance for the biological effect and consequently for the clinical defects. Comparative analyses of tissue areas containing groups of different cell types may then be interesting for some issues, in order to compare a whole molecular environment to another one in the same anatomopathological context.

Among direct tissue analyses modes, two categories of investigations can be done. MALDI profiling consists in the study of molecular localization of compounds and can be combined with parallel shotgun proteomic methods. Imaging methods give less detailed molecular information, but is more focused on the accurate mapping of the detected compounds through tissue area.

In 2007, a concept of direct tissue proteomics (DTP) was proposed for high-throughput examination of tissue microarray samples. However, contrary to the classical workflow, tissue section chemical treatment involved a first step of scrapping each FFPE tissue spot with a razor blade from the glass slide. The tissues were then transferred into a tube and processed with RIPA buffer and finally submitted to boiling as an AR step (Hwang et al., 2007). Afterward, several teams proved that it was possible to perform the AR directly on tissue sections. These applications were mainly dedicated to MALDI imaging analyses (Bonnel et al., 2011; Casadonte and Caprioli, 2011; Gustafsson et al., 2010). However, more recently, Longuespée used citric acid antigen retrieval (CAAR) before shotgun proteomics associated to global profiling proteomics (Longuespee et al., 2013). In this work, tryptic digestion was directly performed on selected areas of ovarian and fallopian tube serous cancer tissue sections. The aim of this study was to bring some proteomic elements reinforcing the theory stating that ovarian serous epithelial ovarian cancer is caused by an intrusion of cells coming from the close fallopian tube tissue (Kurman and Shih Ie, 2010). By nanoLC-MS/MS experiments followed by bioinformatics analysis using Blast2GO, String, and Cytoscape, it was possible to assess the common proteins shared by serous ovarian cancer tissue and its related fallopian tube tissue in order to determine that a metastasis process occurs from fallopian tube to the ovary in a serous ovarian cancer context. A second aim of the study was to find some specific markers of each specific pathology, namely serous fallopian tube cancer and serous ovarian cancer. This allowed the finding that some protein markers already described as ovarian cancer marker were actually fallopian tube cancer ones. Among these markers, periostin was found among these tubal markers that reinforced the metastasis theory in serous ovarian cancer environment. This whole investigation proved the high relevance of "on-tissue proteomics" approach for clinical questions. By this experiment methodology, it was possible to address a clinical issue with limited clinical cases as tissues sections coming from the same patient, this eliminating any inter-subject variability.

Figure 2 illustrates the adopted workflow and the results of this study.

Recent improvements of this method have been proposed concerning on-tissue trypsin deposition and tryptic peptides extraction by the same team, using nano spotting and Liquid Extraction Surface Analysis devices (Wisztorski et al., 2013). A procedure was also recently proposed by Harris et al. for both tryptic digestion and extraction of peptides from tissue sections (Harris et al., 2013). This method was based on the use of a polymerized hydrogel containing Triton X100 for on tissue chemical treatment and trypsin for digestion. Unfortunately, the method has only been applied to fr/fr tissues. On the other hand, this technique presents the great advantage to be compatible with MALDI Imaging analysis, as it was shown using MSI combined with ion mobility spectroscopy for lipids from the same tissue section (Jackson et al., 2007).
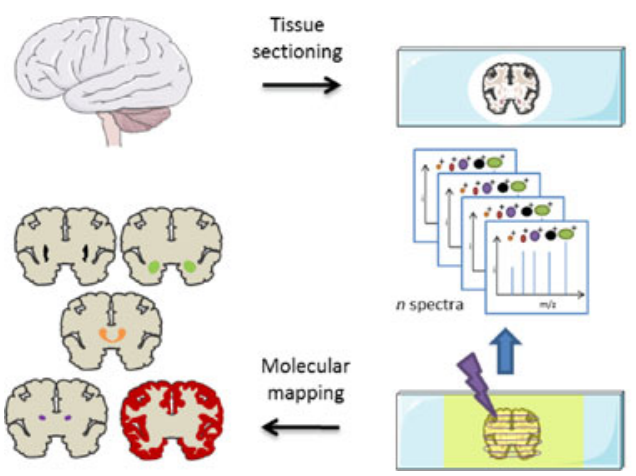

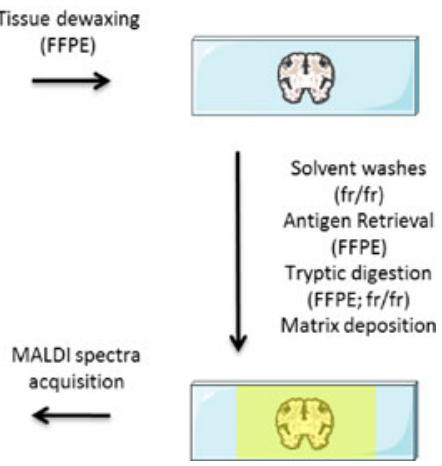

FIG. 3. MALDI imaging workflow. For MALDI imaging experiments, tissue sections are dropped on conductive glass slides. Sample preparations are then adapted depending on the nature of the tissue sample (FFPE or fr/fr). Then, matrix is uniformly deposited on the tissue section using dedicated devices. A laser beam subsequently irradiates the preparation following a given step length and a MALDI spectrum is acquired for each position. Using adapted software, the different detected ions are then mapped through the tissue section, in function of their differential intensities. The "molecular maps" are called images. (FFPE, formalin fixed and paraffin embedded; fr/fr, fresh frozen; MALDI, matrix assisted laser desorption ionization.) 


\section{MALDI Mass Spectrometry Imaging}

The ultimate "molecular histology" method for wide applications in clinical proteomics and pharmacology

MS imaging is the most striking evidence of the reliability between 'omics' and classical histology. Indeed, MSI relies on classical histology and direct mapping of hundreds of compounds of diverse natures on tissue sections.

Among the MS sources for MSI, MALDI is currently the most described. It was introduced in the 1980s and relies on the use of solid samples as analytes (Hillenkamp and Karas, 1990). Soon after, in the early 1990s, authors benefited from the fact that samples for MALDI need to be solid to study mollusk neuropeptides processing directly on animals sections (Jimenez et al., 1994). The method was then extended to other models (Garden et al., 1996; Stahl et al., 1997; van Strien et al., 1996). In 1997, Caprioli proposed an improvement of the method consisting in its automation in order to acquire spectra from areas of the samples. From these data, molecular images can be reconstructed to map different compounds in the sample areas of interest (Caprioli et al., 1997). Figure 3 illustrates MALDI imaging workflow.

Since its introduction, a growing interest emerged in different teams to improve the method and its applications in many fields. Improvements were made on analysis speed, mass range (Franck et al., 2010; van Remoortere et al., 2010), spatial and spectral resolutions (Rompp and Spengler, 2013), targeted imaging (Longuespee et al., 2013; Stauber et al., 2010), and data processing (Bonnel et al., 2011; Jones et al., 2012). Also, substantial efforts are being made to bring some clues to address ion suppression effects issues (Jadoul et al., 2014).

MALDI imaging has found a large panel of applications in pharmacology and pathology fields (El Ayed et al., 2010; Longuespee et al., 2012; 2014a; McDonnell et al., 2010; Meding et al., 2012; Willems et al., 2010). This technology is a valuable tool for biomarker hunting in pathology and is complementary to the use of classical methods in histopathology (Meding et al., 2012). Biological assays are also possible for the functional validation of the discovered biomarkers (Aichler et al., 2013).

Until recently, identification of $\mathrm{m} / \mathrm{z}$ markers obtained with MALDI imaging has remained elusive. Though identification of large proteins can be established directly on tissues using In Source Decay (ISD) procedures (Ait-Belkacem et al., 2014; Ait-Belkacem et al., 2013; Bonnel et al., 2011; Calligaris et al., 2013). In parallel, methods have been used in combination to MALDI imaging to solve this issue. In 2013, Maier et al. published the public MaTisse database of MALDIMSI identifications from fr/fr tissues (Maier et al., 2013). Based on top-down and bottom-up identification strategies, they compiled the proteins that can potentially be found in series of normal and fr/fr tissues. Meding et al. (2013) established tryptic peptides reference data sets in order to associate MS proteolytic peptides detection in tissues with their identification for bottom-up MALDI-MSI approaches. More recently, Longuespée used proteins extraction with hexafluoroisopropanol (HFIP) on fresh fr/fr tissue sections with parallel 2DE analysis to cross correlate the detected MS signals on tissue (Longuespee et al., 2014b).
All these elements make MALDI-MSI very versatile and of most value within "molecular histology" approaches at this time.

\section{Conclusions}

Histology is an old science born after considering the high level of organ complexity and the existence of molecular communication networks among different cell types in order to form a functional tissue. Through the years, advances in chemistry and physics helped histologists to better understand the molecular actors of the tissue physiological functions and the development of a given pathology. A real molecular dimension was then progressively added to classical histology, especially with the use of MS methods.

Today, the available tools for tissue sampling and analysis are extremely varied and allow researchers to address many questions using the most relevant approaches. Thereby, the complex composition of tissues can be more precisely described.

Proteomics instrumentations, specific biochemical preparations, and sampling methods such as LCM altogether allow for the deep exploration and comparison of different proteomes between regions of interest in tissues with up to $10^{4}$ detected proteins.

MALDI MS imaging that allows for differential mapping of hundreds of compounds on a tissue section is currently the most striking illustration of association between "classical", and "molecular" histology.

\section{Acknowledgments}

RL acknowledges the University of Liège for his "Postdoc In" fellowship funding. This work was supported by grants from FNRS.

\section{Author Disclosure Statement}

The authors declare that there are no conflicting financial interests.

\section{References}

Addis MF, Tanca A, Pagnozzi D, et al. (2009). Generation of high-quality protein extracts from formalin-fixed, paraffinembedded tissues. Proteomics 9, 3815-3823.

Aggarwal K, Choe LH, and Lee KH. (2006). Shotgun proteomics using the iTRAQ isobaric tags. Briefings Funct Genomics Proteomics 5, 112-120.

Aichler M, Elsner M, Ludyga N, et al. (2013). Clinical response to chemotherapy in oesophageal adenocarcinoma patients is linked to defects in mitochondria. J Pathol 230, 410-419.

Ait-Belkacem R, Berenguer C, Villard C, et al. (2014). MALDI imaging and in-source decay for top-down characterization of glioblastoma. Proteomics 14, 1290-1301.

Ait-Belkacem R, Calligaris D, Sellami L, et al. (2013). Tubulin isoforms identified in the brain by MALDI in-source decay. $\mathrm{J}$ Proteomics 79, 172-179.

Alkhas A, Hood BL, Oliver K, et al. (2011). Standardization of a sample preparation and analytical workflow for proteomics of archival endometrial cancer tissue. J Proteome Res 10, 5264-5271.

An HJ, Froehlich JW, and Lebrilla CB. (2009). Determination of glycosylation sites and site-specific heterogeneity in glycoproteins. Curr Opinion Chem Biol 13, 421-426. 
Avrameas S, and Uriel J. (1966). [Method of antigen and antibody labelling with enzymes and its immunodiffusion application]. C R Acad Sci Hebd Seances Acad Sci D 262, 2543-2545.

Azimzadeh O, Barjaktarovic Z, Aubele M, et al. (2010). Formalin-fixed paraffin-embedded (FFPE) proteome analysis using gel-free and gel-based proteomics. J Proteome Res 9, 4710-4720.

Baker H, Patel V, Molinolo AA, et al. (2005). Proteome-wide analysis of head and neck squamous cell carcinomas using laser-capture microdissection and tandem mass spectrometry. Oral Oncol 41, 183-199.

Becker KF, Schott C, Hipp S, et al. (2007). Quantitative protein analysis from formalin-fixed tissues: Implications for translational clinical research and nanoscale molecular diagnosis. J Pathol 211, 370-378.

Boersema PJ, Mohammed S, and Heck AJ. (2009). Phosphopeptide fragmentation and analysis by mass spectrometry. $\mathbf{J}$ Mass Spectrom 44, 861-878.

Bondarenko PV, Chelius D, and Shaler TA. (2002). Identification and relative quantitation of protein mixtures by enzymatic digestion followed by capillary reversed-phase liquid chromatography-tandem mass spectrometry. Anal Chem 74, 4741-4749.

Bonnel D, Longuespee R, Franck J, et al. (2011). Multivariate analyses for biomarkers hunting and validation through ontissue bottom-up or in-source decay in MALDI-MSI: Application to prostate cancer. Anal Bioanal Chem 401, 149-165.

Bonner RF, Emmert-Buck M, Cole K, et al. (1997). Laser capture microdissection: Molecular analysis of tissue. Science 278, 1481,1483.

Boytard L, Spear R, Chinetti-Gbaguidi G, et al. (2013). Role of proinflammatory CD68(+) mannose receptor(-) macrophages in peroxiredoxin-1 expression and in abdominal aortic aneurysms in humans. Arterioscler Thromb Vasc Biol 33, 431-438.

Braakman RB, Luider TM, Martens JW, Foekens JA, and Umar A. (2011). Laser capture microdissection applications in breast cancer proteomics. Methods Mol Biol 755, 143-154.

Braakman RB, Tilanus-Linthorst MM, Liu NQ, et al. (2012). Optimized nLC-MS workflow for laser capture microdissected breast cancer tissue. J Proteomics 75, 2844-2854.

Buckanovich RJ, Sasaroli D, O’Brien-Jenkins A, et al. (2006). Use of immuno-LCM to identify the in situ expression profile of cellular constituents of the tumor microenvironment. Cancer Biol Ther 5, 635-642.

Calligaris D, Longuespee R, Debois D, et al. (2013). Selected protein monitoring in histological sections by targeted MALDI-FTICR in-source decay imaging. Anal Chem 85, 2117-2126.

Calvo E, Camafeita E, Fernandez-Gutierrez B, and Lopez JA. (2011). Applying selected reaction monitoring to targeted proteomics. Expert Rev Proteomics 8, 165-173.

Caprioli RM, Farmer TB, and Gile J. (1997). Molecular imaging of biological samples: Localization of peptides and proteins using MALDI-TOF MS. Anal Chem 69, 4751-4760.

Casadonte R, and Caprioli RM. (2011). Proteomic analysis of formalin-fixed paraffin-embedded tissue by MALDI imaging mass spectrometry. Nat Protoc 6, 1695-1709.

Chen JS, Chen KT, Fan CW, et al. (2010). Comparison of membrane fraction proteomic profiles of normal and cancerous human colorectal tissues with gel-assisted digestion and iTRAQ labeling mass spectrometry. FEBS J 277, 3028-3038.

Cheng AL, Huang WG, Chen ZC, et al. (2008). Identification of novel nasopharyngeal carcinoma biomarkers by laser capture microdissection and proteomic analysis. Clin Cancer Res 14, 435-445.

Christin C, Bischoff R, and Horvatovich P. (2011). Data processing pipelines for comprehensive profiling of proteomics samples by label-free LC-MS for biomarker discovery. Talanta 83, 1209-1224.

Chu WS, Liang Q, Liu J, et al. (2005). A nondestructive molecule extraction method allowing morphological and molecular analyses using a single tissue section. Lab Invest 85, 1416-1428.

Coons AH, and Kaplan MH. (1950). Localization of antigen in tissue cells; Improvements in a method for the detection of antigen by means of fluorescent antibody. J Exp Med 91, 113.

Cox J, and Mann M. (2009). Computational principles of determining and improving mass precision and accuracy for proteome measurements in an Orbitrap. J Am Soc Mass Spectrom 20, 1477-1485.

Craven RA, Cairns DA, Zougman A, Harnden P, Selby PJ, and Banks RE. (2013). Proteomic analysis of formalin-fixed paraffin-embedded renal tissue samples by label-free MS: Assessment of overall technical variability and the impact of block age. Proteomics Clin Appl 7, 273-282.

Crockett DK, Lin Z, Vaughn CP, Lim MS, and ElenitobaJohnson KS. (2005). Identification of proteins from formalinfixed paraffin-embedded cells by LC-MS/MS. Lab Invest 85, 1405-1415.

Desiere F, Deutsch EW, King NL, et al., (2006). The PeptideAtlas project. Nucleic Acids Res 34, D655-658.

Desouza L, Diehl G, Rodrigues MJ, et al. (2005). Search for cancer markers from endometrial tissues using differentially labeled tags iTRAQ and cICAT with multidimensional liquid chromatography and tandem mass spectrometry. J Proteome Res 4, 377-386.

Deterding LJ, Moseley MA, Tomer KB, and Jorgenson JW. (1991). Nanoscale separations combined with tandem mass spectrometry. J Chromatog 554, 73-82.

Diament BJ, and Noble WS. (2011). Faster SEQUEST searching for peptide identification from tandem mass spectra. J Proteome Res 10, 3871-3879.

El Ayed M, Bonnel D, Longuespee R, et al. (2010). MALDI imaging mass spectrometry in ovarian cancer for tracking, identifying, and validating biomarkers. Med Sci Monit 16, BR233-245.

Emmert-Buck MR, Bonner RF, Smith PD, et al. (1996). Laser capture microdissection. Science 274, 998-1001.

Espina V, Milia J, Wu G, Cowherd S, and Liotta LA. (2006a). Laser capture microdissection. Methods Mol Biol 319, 213 229.

Espina V, Wulfkuhle JD, Calvert VS, et al. (2006b). Lasercapture microdissection. Nat Protoc 1, 586-603.

Fend F, Kremer M, and Quintanilla-Martinez L. (2000). Laser capture microdissection: Methodical aspects and applications with emphasis on immuno-laser capture microdissection. Pathobiology 68, 209-214.

Fenn JB, Mann M, Meng CK, Wong SF, and Whitehouse CM. (1989). Electrospray ionization for mass spectrometry of large biomolecules. Science 246, 64-71.

Fey SJ, and Larsen PM. (2001). 2D or not 2D. Two-dimensional gel electrophoresis. Curr Opinion Chem Biol 5, 26-33.

Ficarro SB, McCleland ML, Stukenberg PT, et al. (2002). Phosphoproteome analysis by mass spectrometry and its application to Saccharomyces cerevisiae. Nature Biotechnol 20, 301-305. 
Fowler CB, Waybright TJ, Veenstra TD, O'leary TJ, and Mason JT. (2012). Pressure-assisted protein extraction: A novel method for recovering proteins from archival tissue for proteomic analysis. J Proteome Res 11, 2602-2608.

Fraenkel-Conrat H, and Olcott HS. (1946). Reaction of formaldehyde with proteins; Participation of the guanidyl groups and evidence of crosslinking. J Am Chem Soc 68, 34-37.

Fraenkel-Conrat H, and Olcott HS. (1948a). The reaction of formaldehyde with proteins; Cross-linking between amino and primary amide or guanidyl groups. J Am Chem Soc 70, 2673-2684.

Fraenkel-Conrat H, and Olcott HS. (1948b). Reaction of formaldehyde with proteins; Cross-linking of amino groups with phenol, imidazole, or indole groups. J Biol Chem 174, 827-843.

Franck J, Longuespee R, Wisztorski M, et al. (2010). MALDI mass spectrometry imaging of proteins exceeding 30,000 daltons. Med Sci Monit 16, BR293-299.

Frank A, and Pevzner P. (2005). PepNovo: De novo peptide sequencing via probabilistic network modeling. Anal Chem 77, 964-973.

Garbis SD, Tyritzis SI, Roumeliotis T, et al. (2008). Search for potential markers for prostate cancer diagnosis, prognosis and treatment in clinical tissue specimens using amine-specific isobaric tagging (iTRAQ) with two-dimensional liquid chromatography and tandem mass spectrometry. J Proteome Res 7, 3146-3158.

Garden RW, Moroz LL, Moroz TP, Shippy SA, and Sweedler JV. (1996). Excess salt removal with matrix rinsing: Direct peptide profiling of neurons from marine invertebrates using matrix-assisted laser desorption/ionization time-of-flight mass spectrometry. J Mass Spectrom 31, 1126-1130.

Giusti L, and Lucacchini A. (2013). Proteomic studies of formalin-fixed paraffin-embedded tissues. Expert Rev Proteomics 10, 165-177.

Gu Y, Wu SL, Meyer JL, et al. (2007). Proteomic analysis of high-grade dysplastic cervical cells obtained from ThinPrep slides using laser capture microdissection and mass spectrometry. J Proteome Res 6, 4256-4268.

Guo T, Wang W, Rudnick PA, et al. (2007). Proteome analysis of microdissected formalin-fixed and paraffin-embedded tissue specimens. J Histochem Cytochem 55, 763-772.

Gustafsson JO, Oehler MK, McColl SR, and Hoffmann P. (2010). Citric acid antigen retrieval (CAAR) for tryptic peptide imaging directly on archived formalin-fixed paraffinembedded tissue. J Proteome Res 9, 4315-4328.

Hardman M, and Makarov AA. (2003). Interfacing the orbitrap mass analyzer to an electrospray ion source. Anal Chem 75, 1699-1705.

Harris GA, Nicklay JJ, and Caprioli RM. (2013). Localized in situ hydrogel-mediated protein digestion and extraction technique for on-tissue analysis. Anal Chem 85, 2717-2723.

Hatakeyama H, Kondo T, Fujii K, et al. (2006). Protein clusters associated with carcinogenesis, histological differentiation and nodal metastasis in esophageal cancer. Proteomics 6, 6300-6316.

Higgs RE, Knierman MD, Gelfanova V, Butler JP, and Hale JE. (2005). Comprehensive label-free method for the relative quantification of proteins from biological samples. J Proteome Res 4, 1442-1450.

Hill JJ, Tremblay TL, Pen A, et al. (2011). Identification of vascular breast tumor markers by laser capture microdissection and label-free LC-MS. J Proteome Res 10, 2479-2493.
Hillenkamp F, and Karas M. (1990). Mass spectrometry of peptides and proteins by matrix-assisted ultraviolet laser desorption/ionization. Methods Enzymol 193, 280-295.

Hirosawa M, Hoshida M, Ishikawa M, and Toya T. (1993). MASCOT: Multiple alignment system for protein sequences based on three-way dynamic programming. Computer Applic Biosci CABIOS 9, 161-167.

Hosako M, Muto T, Nakamura Y, et al. (2012). Proteomic study of malignant pleural mesothelioma by laser microdissection and two-dimensional difference gel electrophoresis identified cathepsin D as a novel candidate for a differential diagnosis biomarker. J Proteomics 75, 833-844.

Hwang SI, Thumar J, Lundgren DH, et al. (2007). Direct cancer tissue proteomics: A method to identify candidate cancer biomarkers from formalin-fixed paraffin-embedded archival tissues. Oncogene 26, 65-76.

Ikeda K, Monden T, Kanoh T, et al. (1998). Extraction and analysis of diagnostically useful proteins from formalin-fixed, paraffin-embedded tissue sections. J Histochem Cytochem 46, 397-403.

Jackson SN, Ugarov M, Egan T, et al. (2007). MALDI-ion mobility-TOFMS imaging of lipids in rat brain tissue. J Mass Spectrom 42, 1093-1098.

Jadoul L, Malherbe C, Calligaris D, et al. (2014). Matrixassisted laser desorption/ionization mass spectrometry and Raman spectroscopy: An interesting complementary approach for lipid detection in biological tissues. Eur J Lipid Sci Technol 116 , In press.

Jiang X, Feng S, Tian R, Ye M, and Zou H. (2007). Development of efficient protein extraction methods for shotgun proteome analysis of formalin-fixed tissues. J Proteome Res 6, 1038-1047.

Jimenez CR, Van Veelen PA, Li KW, et al. (1994). Neuropeptide expression and processing as revealed by direct matrix-assisted laser desorption ionization mass spectrometry of single neurons. J Neurochem 62, 404-407.

Johann DJ, Rodriguez-Canales J, Mukherjee S, et al. (2009). Approaching solid tumor heterogeneity on a cellular basis by tissue proteomics using laser capture microdissection and biological mass spectrometry. J Proteome Res 8, 23102318.

Jones EA, Deininger SO, Hogendoorn PC, Deelder AM, and Mcdonnell LA. (2012). Imaging mass spectrometry statistical analysis. J Proteomics 75, 4962-4989.

Jones P, Cote RG, Martens L, et al. (2006). PRIDE: A public repository of protein and peptide identifications for the proteomics community. Nucleic Acids Res 34, D659-663.

Kakimoto Y, Tsuruyama T, Yamamoto T, et al. (2012). Novel in situ pretreatment method for significantly enhancing the signal in MALDI-TOF MS of formalin-fixed paraffin-embedded tissue sections. PLoS One 7, e41607.

Kelly RT, Tolmachev AV, Page JS, Tang K, and Smith RD. (2010). The ion funnel: Theory, implementations, and applications. Mass Spectrom Rev 29, 294-312.

Kim T, Tolmachev AV, Harkewicz R, et al. (2000). Design and implementation of a new electrodynamic ion funnel. Anal Chem 72, 2247-2255.

Kiyonami R, Schoen A, Prakash A, et al. (2011). Increased selectivity, analytical precision, and throughput in targeted proteomics. Mol Cell Proteomics 10, M110 002931.

Kocher T, Pichler P, Mazanek M, Swart R, and Mechtler K. (2011). Altered Mascot search results by changing the $\mathrm{m} / \mathrm{z}$ range of MS/MS spectra: Analysis and potential applications. Anal Bioanal Chem 400, 2339-2347. 
Kolble K. (2000). The LEICA microdissection system: Design and applications. J Mol Med (Berl) 78, B24-25.

Kurman RJ, and Shih Ie M. (2010). The origin and pathogenesis of epithelial ovarian cancer: A proposed unifying theory. Am J Surg Pathol 34, 433-443.

Lam H, Deutsch EW, Eddes JS, et al., (2007). Development and validation of a spectral library searching method for peptide identification from MS/MS. Proteomics 7, 655-667.

Leong AS. (1996). Microwaves in diagnostic immunohistochemistry. Eur J Morphol 34, 381-383.

Leong AS, Milios J, and Duncis CG. (1988). Antigen preservation in microwave-irradiated tissues: A comparison with formaldehyde fixation. J Pathol 156, 275-282.

Leong AS, and Wright J. (1987). The contribution of immunohistochemical staining in tumour diagnosis. Histopathology $11,1295-1305$.

Li B, An HJ, Hedrick JL, and Lebrilla CB. (2009). Collisioninduced dissociation tandem mass spectrometry for structural elucidation of glycans. Methods Mol Biol 534, 133-145.

Li C, Hong Y, Tan YX, et al. (2004). Accurate qualitative and quantitative proteomic analysis of clinical hepatocellular carcinoma using laser capture microdissection coupled with isotope-coded affinity tag and two-dimensional liquid chromatography mass spectrometry. Mol Cell Proteomics 3, 399409.

Li C, Yi H, Tan YX, et al. (2008). Analysis of microdissected cells by two-dimensional LC-MS approaches. Methods Mol Biol 428, 193-208.

Lilley KS, and Friedman DB. (2004). All about DIGE: Quantification technology for differential-display 2D-gel proteomics. Expert Rev Proteomics 1, 401-409.

Liu NQ, Braakman RB, Stingl C, et al. (2012). Proteomics pipeline for biomarker discovery of laser capture microdissected breast cancer tissue. J Mammary Gland Biol Neoplasia 17, 155-164.

Liu Y, Wu J, Yan G, et al. (2010). Proteomic analysis of prolactinoma cells by immuno-laser capture microdissection combined with online two-dimensional nano-scale liquid chromatography/mass spectrometry. Proteome Sci 8, 2.

Longuespee R, Boyon C, Castellier C, et al. (2012). The Cterminal fragment of the immunoproteasome PA28S (Reg alpha) as an early diagnosis and tumor-relapse biomarker: Evidence from mass spectrometry profiling. Histochem Cell Biol 138, 141-154.

Longuespee R, Boyon C, Desmons A, et al. (2014a). Spectroimmunohistochemistry: A novel form of MALDI mass spectrometry imaging coupled to immunohistochemistry for tracking antibodies. Omics 18, 132-141.

Longuespee R, Gagnon H, Boyon C, et al. (2013). Proteomic analyses of serous and endometrioid epithelial ovarian cancers. Cases studies: Molecular insights of a possible histological etiology of serous ovarian cancer. Proteomics Clin Appl 7, 337-354.

Longuespee R, Tastet C, Desmons A, et al. (2014b). HFIP extraction followed by 2D CTAB-SDS PAGE separation: A new methodology for protein identification from tissue sections after MALDI mass spectrometry profiling for personalized medicine research. OMICS 18, 374-384.

Maes E, Broeckx V, Mertens I, et al. (2013). Analysis of the formalin-fixed paraffin-embedded tissue proteome: Pitfalls, challenges, and future prospectives. Amino Acids 45, 205-218.

Magdeldin S, and Yamamoto T. (2012). Toward deciphering proteomes of formalin-fixed paraffin-embedded (FFPE) tissues. Proteomics 12, 1045-1058.
Maier SK, Hahne H, Moghaddas Gholami A, et al. (2013). Comprehensive identification of proteins from MALDI imaging. Mol Cell Proteomics 10, 2901-2910.

Makarov A, Denisov E, Kholomeev A, et al. (2006). Performance evaluation of a hybrid linear ion trap/orbitrap mass spectrometer. Anal Chem 78, 2113-2120.

Makarov A, Denisov E, and Lange O. (2009). Performance evaluation of a high-field Orbitrap mass analyzer. J Am Soc Mass Spectrom 20, 1391-1396.

Mann M, and Kelleher NL. (2008). Precision proteomics: The case for high resolution and high mass accuracy. Proc Natl Acad Sci USA 105, 18132-18138.

Mann M, and Wilm M. (1994). Error-tolerant identification of peptides in sequence databases by peptide sequence tags. Anal Chem 66, 4390-4399.

Marginean I, Page JS, Tolmachev AV, Tang K, and Smith RD. (2010). Achieving 50\% ionization efficiency in subambient pressure ionization with nanoelectrospray. Anal Chem 82, 9344-9349.

Mason DY, and Sammons R. (1978). Alkaline phosphatase and peroxidase for double immunoenzymatic labelling of cellular constituents. J Clin Pathol 31, 454-460.

Masselon C, Anderson GA, Harkewicz R, Bruce JE, Pasa-Tolic L, and Smith RD. (2000). Accurate mass multiplexed tandem mass spectrometry for high-throughput polypeptide identification from mixtures. Anal Chem 72, 1918-1924.

May C, Brosseron F, Chartowski P, Meyer HE, and Marcus K. (2012). Differential proteome analysis using 2D-DIGE. Methods Mol Biol 893, 75-82.

McDonnell LA, Corthals GL, Willems SM, Van Remoortere A, Van Zeijl RJ, and Deelder AM. (2010). Peptide and protein imaging mass spectrometry in cancer research. J Proteomics 73, 1921-1944.

Meding S, Balluff B, Elsner M, et al., (2012). Tissue-based proteomics reveals FXYD3, S100A11 and GSTM3 as novel markers for regional lymph node metastasis in colon cancer. J Pathol 228, 459-470.

Meding S, Martin K, Gustafsson OJ, et al. (2013). Tryptic peptide reference data sets for MALDI imaging mass spectrometry on formalin-fixed ovarian cancer tissues. J Proteome Res 12, 308-315.

Michalski A, Damoc E, Hauschild JP, et al. (2011). Mass spectrometry-based proteomics using Q Exactive, a highperformance benchtop quadrupole Orbitrap mass spectrometer. Mol Cell Proteomics 10, M111 011015.

Micke P, Ostman A, Lundeberg J, and Ponten F. (2005). Laserassisted cell microdissection using the PALM system. Methods Mol Biol 293, 151-166.

Muraoka S, Kume H, Watanabe S, et al. (2012). Strategy for SRM-based verification of biomarker candidates discovered by iTRAQ method in limited breast cancer tissue samples. J Proteome Res 11, 4201-4210.

Nadji M. (1986). Immunoperoxidase techniques. I. Facts and artifacts. Am J Dermatopathol 8, 32-36.

Nagaraj N, D'souza RC, Cox J, Olsen JV, and Mann M. (2010). Feasibility of large-scale phosphoproteomics with higher energy collisional dissociation fragmentation. J Proteome Res 9, 6786-6794.

Nakamura N, Ruebel K, Jin L, Qian X, Zhang H, and Lloyd RV. (2007). Laser capture microdissection for analysis of single cells. Methods Mol Med 132, 11-18.

Nakane PK. (1968). Simultaneous localization of multiple tissue antigens using the peroxidase-labeled antibody method: A study on pituitary glands of the rat. J Histochem Cytochem 16, 557-560. 
Nakane PK, and Pierce GB, Jr. (1966). Enzyme-labeled antibodies: Preparation and application for the localization of antigens. J Histochem Cytochem 14, 929-931.

Nakatani S, Wei M, Ishimura E, et al. (2012). Proteome analysis of laser microdissected glomeruli from formalin-fixed paraffin-embedded kidneys of autopsies of diabetic patients: $\mathrm{Ne}$ phronectin is associated with the development of diabetic glomerulosclerosis. Nephrol Dial Transplant 27, 1889-1897.

Narumi R, Murakami T, Kuga T, et al. (2012). A strategy for large-scale phosphoproteomics and SRM-based validation of human breast cancer tissue samples. J Proteome Res 11, 5311-5322.

Nazarian J, Santi M, Hathout Y, and Macdonald TJ. (2008). Protein profiling of formalin fixed paraffin embedded tissue: Identification of potential biomarkers for pediatric brainstem glioma. Proteomics Clin Appl 2, 915-924.

Neilson KA, Ali NA, Muralidharan S, et al.,(2011). Less label, more free: Approaches in label-free quantitative mass spectrometry. Proteomics 11, 535-553.

Nirmalan NJ, Harnden P, Selby PJ, and Banks RE. (2008). Mining the archival formalin-fixed paraffin-embedded tissue proteome: opportunities and challenges. Mol Biosyst 4, 712 720.

Nirmalan NJ, Harnden P, Selby PJ, and Banks RE. (2009). Development and validation of a novel protein extraction methodology for quantitation of protein expression in formalin-fixed paraffin-embedded tissues using western blotting. J Pathol 217, 497-506.

Nirmalan NJ, Hughes C, Peng J, et al. (2011). Initial development and validation of a novel extraction method for quantitative mining of the formalin-fixed, paraffin-embedded tissue proteome for biomarker investigations. J Proteome Res 10, 896-906.

Nishimura T, Nomura M, Tojo H, et al. (2010). Proteomic analysis of laser-microdissected paraffin-embedded tissues: (2) MRM assay for stage-related proteins upon nonmetastatic lung adenocarcinoma. J Proteomics 73, 1100-1110.

Oda Y, Nagasu T, and Chait BT. (2001). Enrichment analysis of phosphorylated proteins as a tool for probing the phosphoproteome. Nature Biotechnol 19, 379-382.

Olsen JV, Schwartz JC, Griep-Raming J, et al, (2009). A dual pressure linear ion trap Orbitrap instrument with very high sequencing speed. Mol Cell Proteomics 8, 2759-2769.

Ostasiewicz P, Zielinska DF, Mann M, and Wisniewski JR. (2010). Proteome, phosphoproteome, and N-glycoproteome are quantitatively preserved in formalin-fixed paraffin-embedded tissue and analyzable by high-resolution mass spectrometry. J Proteome Res 9, 3688-3700.

Page JS, Tang K, Kelly RT, and Smith RD. (2008). Subambient pressure ionization with nanoelectrospray source and interface for improved sensitivity in mass spectrometry. Anal Chem 80, 1800-1805.

Page JS, Tolmachev AV, Tang K, and Smith RD. (2006). Theoretical and experimental evaluation of the low $\mathrm{m} / \mathrm{z}$ transmission of an electrodynamic ion funnel. J Am Soc Mass Spectrom 17, 586-592.

Palmer-Toy DE, Krastins B, Sarracino DA, Nadol JB, Jr., and Merchant SN. (2005). Efficient method for the proteomic analysis of fixed and embedded tissues. J Proteome Res 4, 2404-2411.

Palmer-Toy DE, Sarracino DA, Sgroi D, Levangie R, and Leopold PE. (2000). Direct acquisition of matrix-assisted laser desorption/ionization time-of-flight mass spectra from laser capture microdissected tissues. Clin Chem 46, 1513-1516.
Pan S, Chen R, Stevens T, et al. (2011). Proteomics portrait of archival lesions of chronic pancreatitis. PLoS One 6, e27574.

Panchaud A, Jung S, Shaffer SA, Aitchison JD, and Goodlett DR. (2011). Faster, quantitative, and accurate precursor acquisition independent from ion count. Anal Chem 83, 22502257.

Panchaud A, Scherl A, Shaffer SA, et al. (2009). Precursor acquisition independent from ion count: How to dive deeper into the proteomics ocean. Anal Chem 81, 6481-6488.

Pietersen CY, Lim MP, and Woo TU. (2009). Obtaining high quality RNA from single cell populations in human postmortem brain tissue. J Vis Exp 30, 1444.

Prieto DA, Hood BL, Darfler MM, et al. (2005). Liquid Tissue: Proteomic profiling of formalin-fixed tissues. Biotechniques Suppl, 38, 32-35.

Rezaul K, Thumar JK, Lundgren DH, et al. (2010). Differential protein expression profiles in estrogen receptor-positive and negative breast cancer tissues using label-free quantitative proteomics. Genes Cancer 1, 251-271.

Rompp A, and Spengler B. (2013). Mass spectrometry imaging with high resolution in mass and space. Histochem Cell Biol 139, 759-783.

Sanders ME, Dias EC, Xu BJ, et al. (2008). Differentiating proteomic biomarkers in breast cancer by laser capture microdissection and MALDI MS. J Proteome Res 7, 1500-1507.

Shaffer SA, Prior DC, Anderson GA, Udseth HR, and Smith RD. (1998). An ion funnel interface for improved ion focusing and sensitivity using electrospray ionization mass spectrometry. Anal Chem 70, 4111-4119.

Shekouh AR, Thompson CC, Prime W, et al, (2003). Application of laser capture microdissection combined with twodimensional electrophoresis for the discovery of differentially regulated proteins in pancreatic ductal adenocarcinoma. Proteomics 3, 1988-2001.

Shi H, Hood KA, Hayes MT, and Stubbs RS. (2011). Proteomic analysis of advanced colorectal cancer by laser capture microdissection and two-dimensional difference gel electrophoresis. J Proteomics 75, 339-351.

Shi SR, Liu C, Balgley BM, Lee C, and Taylor CR. (2006). Protein extraction from formalin-fixed, paraffin-embedded tissue sections: Quality evaluation by mass spectrometry. J Histochem Cytochem 54, 739-743.

Shvartsburg AA, Seim TA, Danielson WF, et al. (2013). Highdefinition differential ion mobility spectrometry with resolving power up to 500. J Am Soc Mass Spectrom 24, 109-114.

Shvartsburg AA, Singer D, Smith RD, and Hoffmann R. (2011). Ion mobility separation of isomeric phosphopeptides from a protein with variant modification of adjacent residues. Anal Chem 83, 5078-5085.

Singer SJ. (1959). Preparation of an electron-dense antibody conjugate. Nature 183, 1523-1524.

Skvortsov S, Schafer G, Stasyk T, et al. (2011). Proteomics profiling of microdissected low- and high-grade prostate tumors identifies Lamin A as a discriminatory biomarker. J Proteome Res 10, 259-268.

Stahl B, Linos A, Karas M, Hillenkamp F, and Steup M. (1997). Analysis of fructans from higher plants by matrix-assisted laser desorption/ionization mass spectrometry. Anal Biochem 246, 195-204.

Stauber J, Ayed ME, Wisztorski M, Salzet M, and Fournier I. (2010). Specific MALDI-MSI: Tag-Mass. Methods Mol Biol 656, 339-361.

Sternberger LA, Hardy PH, Jr., Cuculis JJ, and Meyer HG. (1970). The unlabeled antibody enzyme method of immu- 
nohistochemistry: Preparation and properties of soluble antigen-antibody complex (horseradish peroxidase-antihorseradish peroxidase) and its use in identification of spirochetes. J Histochem Cytochem 18, 315-333.

Stingl C, Van Vilsteren FG, Guzel C, et al. (2011). Reproducibility of protein identification of selected cell types in Barrett's esophagus analyzed by combining laser-capture microdissection and mass spectrometry. J Proteome Res 10, 288-298.

Sugihara Y, Taniguchi H, Kushima R, et al. (2013). Laser microdissection and two-dimensional difference gel electrophoresis reveal proteomic intra-tumor heterogeneity in colorectal cancer. J Proteomics 78, 134-147.

Swanson PE. (1997). HIERanarchy: The state of the art in immunohistochemistry. Am J Clin Pathol 107, 139-140.

Tabb DL, Fernando CG, and Chambers MC. (2007). MyriMatch: Highly accurate tandem mass spectral peptide identification by multivariate hypergeometric analysis. J Proteome Res 6, 654-661.

Tabb DL, Ma ZQ, Martin DB, Ham AJ, and Chambers MC. (2008). DirecTag: Accurate sequence tags from peptide MS/ MS through statistical scoring. J Proteome Res 7, 3838-3846.

Tabb DL, Saraf A, and Yates JR, 3rd. (2003). GutenTag: Highthroughput sequence tagging via an empirically derived fragmentation model. Anal Chem 75, 6415-6421.

Tanaka K, Waki H, Ido Y, et al. (1988). Protein and polymer analyses up to $\mathrm{m} / \mathrm{z} 100000$ by laser ionization time-of-flight mass spectrometry. Rapid Commun Mass Spectrom 2, 151-153.

Tang K, Page JS, Marginean I, Kelly RT, and Smith RD. (2011). Improving liquid chromatography-mass spectrometry sensitivity using a subambient pressure ionization with nanoelectrospray (SPIN) interface. J Am Soc Mass Spectrom 22, 1318-1325.

Tangrea MA, Mukherjee S, Gao B, et al. (2011). Effect of immunohistochemistry on molecular analysis of tissue samples: Implications for microdissection technologies. J Histochem Cytochem 59, 591-600.

Thakur D, Rejtar T, Wang D, et al. (2011). Microproteomic analysis of 10,000 laser captured microdissected breast tumor cells using short-range sodium dodecyl sulfate-polyacrylamide gel electrophoresis and porous layer open tubular liquid chromatography tandem mass spectrometry. J Chromatogr A 1218, 8168-8174.

Tian Y, Gurley K, Meany DL, Kemp CJ, and Zhang H. (2009). $\mathrm{N}$-linked glycoproteomic analysis of formalin-fixed and paraffin-embedded tissues. J Proteome Res 8, 1657-1662.

Umar A, Kang H, Timmermans AM, Look MP, et al. (2009). Identification of a putative protein profile associated with tamoxifen therapy resistance in breast cancer. Mol Cell Proteomics 8, 1278-1294.

Umar A, Luider TM, Foekens JA, and Pasa-Tolic L. (2007). NanoLC-FT-ICR MS improves proteome coverage attainable for approximately 3000 laser-microdissected breast carcinoma cells. Proteomics 7, 323-329.

Van Remoortere A, Van Zeijl RJ, Van Den Oever N, et al. (2010). MALDI imaging and profiling MS of higher mass proteins from tissue. J Am Soc Mass Spectrom 21, 1922-1929.

Van Strien FJ, Jespersen S, Van Der Greef J, Jenks BG, and Roubos EW. (1996). Identification of POMC processing products in single melanotrope cells by matrix-assisted laser desorption/ionization mass spectrometry. FEBS Lett 379, 165-170.

Venable JD, Dong MQ, Wohlschlegel J, Dillin A, and Yates JR. (2004). Automated approach for quantitative analysis of complex peptide mixtures from tandem mass spectra. Nature Meth 1, 39-45.

Vizcaino JA, Cote R, Reisinger F, et al. (2009). A guide to the Proteomics Identifications Database proteomics data repository. Proteomics 9, 4276-4283.

Vogt A, Fuerholzner B, Kinkl N, Boldt K, and Ueffing M. (2013). Isotope coded protein labeling coupled immunoprecipitation (ICPL-IP): A novel approach for quantitative protein complex analysis from native tissue. Mol Cell Proteomics 12, 1395-1406.

Wang G, Wu WW, Zeng W, Chou CL, and Shen RF. (2006). Label-free protein quantification using LC-coupled ion trap or FT mass spectrometry: Reproducibility, linearity, and application with complex proteomes. J Proteome Res 5, 1214-1223.

Wang LN, Tong SW, Hu HD, et al. (2012). Quantitative proteome analysis of ovarian cancer tissues using a iTRAQ approach. J Cell Biochem 113, 3762-3772.

Wells JM, and Mcluckey SA. (2005). Collision-induced dissociation (CID) of peptides and proteins. Methods Enzymol 402, 148-185.

Wiesner J, Premsler T, and Sickmann A. (2008). Application of electron transfer dissociation (ETD) for the analysis of posttranslational modifications. Proteomics 8, 4466-4483.

Willems SM, Van Remoortere A, Van Zeijl R, Deelder AM, Mcdonnell LA, and Hogendoorn PC. (2010). Imaging mass spectrometry of myxoid sarcomas identifies proteins and lipids specific to tumour type and grade, and reveals biochemical intratumour heterogeneity. J Pathol 222, 400-409.

Wisniewski JR, Dus K, and Mann M. (2013). Proteomic workflow for analysis of archival formalin-fixed and paraffinembedded clinical samples to a depth of 10000 proteins. Proteomics Clin Appl 7, 225-233.

Wisniewski JR, Ostasiewicz P, and Mann M. (2011). High recovery FASP applied to the proteomic analysis of microdissected formalin fixed paraffin embedded cancer tissues retrieves known colon cancer markers. J Proteome Res 10, 3040-3049.

Wisztorski M, Fatou B, Franck J, et al. (2013). Microproteomics by liquid extraction surface analysis: Application to FFPE tissue to study the fimbria region of tubo-ovarian cancer. Proteomics Clin Appl 7, 234-240.

Wong KF, and Luk JM. (2012). Discovery of lamin B1 and vimentin as circulating biomarkers for early hepatocellular carcinoma. Methods Mol Biol 909, 295-310.

$\mathrm{Xu}$ BJ, Caprioli RM, Sanders ME, and Jensen RA. (2002). Direct analysis of laser capture microdissected cells by MALDI mass spectrometry. J Am Soc Mass Spectrom 13, 1292-1297.

Xu BJ, Li J, Beauchamp RD, et al. (2009). Identification of early intestinal neoplasia protein biomarkers using laser capture microdissection and MALDI MS. Mol Cell Proteomics 8, 936-945.

Xu BJ, Shyr Y, Liang X, et al. (2005). Proteomic patterns and prediction of glomerulosclerosis and its mechanisms. J Am Soc Nephrol 16, 2967-2975.

Xu H, Yang L, Wang W, et al. (2008). Antigen retrieval for proteomic characterization of formalin-fixed and paraffinembedded tissues. J Proteome Res 7, 1098-1108.

Yao H, Zhang Z, Xiao Z, et al. (2009). Identification of metastasis associated proteins in human lung squamous carcinoma using two-dimensional difference gel electrophoresis and laser capture microdissection. Lung Cancer 65, 41-48.

Yates JR, 3rd, Morgan SF, Gatlin CL, Griffin PR, and Eng JK. (1998). Method to compare collision-induced dissociation 
spectra of peptides: Potential for library searching and subtractive analysis. Anal Chem 70, 3557-3565.

Zang L, Palmer Toy D, Hancock WS, Sgroi DC, and Karger BL. (2004). Proteomic analysis of ductal carcinoma of the breast using laser capture microdissection, LC-MS, and 16O/ 180 isotopic labeling. J Proteome Res 3, 604-612.

Zanni KL, and Chan GK. (2011). Laser capture microdissection: Understanding the techniques and implications for molecular biology in nursing research through analysis of breast cancer tumor samples. Biol Res Nurs 13, 297-305.

Zhang D, Tai LK, Wong LL, Chiu LL, Sethi SK, and Koay ES. (2005). Proteomic study reveals that proteins involved in metabolic and detoxification pathways are highly expressed in HER-2/neu-positive breast cancer. Mol Cell Proteomics 4, 1686-1696.

Zhang H, Li XJ, Martin DB, and Aebersold R. (2003). Identification and quantification of $\mathrm{N}$-linked glycoproteins using hydrazide chemistry, stable isotope labeling and mass spectrometry. Nature Biotechnol 21, 660-666.

Zhang J, Xin L, Shan B, et al. (2012). PEAKS DB: De novo sequencing assisted database search for sensitive and accurate peptide identification. Mol Cell Proteomics 11, M111 010587.

Zhang Y, Tang H, Cai J, et al. (2011). Ovarian cancer-associated fibroblasts contribute to epithelial ovarian carcinoma metasta- sis by promoting angiogenesis, lymphangiogenesis and tumor cell invasion. Cancer Lett 303, 47-55.

Zhou G, Li H, Decamp D, et al. (2002). 2D differential in-gel electrophoresis for the identification of esophageal scans cell cancer-specific protein markers. Mol Cell Proteomics 1, 117124.

Zhou H, Watts JD, and Aebersold R. (2001). A systematic approach to the analysis of protein phosphorylation. Nature Biotechnol 19, 375-378.

Zhu J, Nie S, Wu J, and Lubman DM. (2013). Target proteomic profiling of frozen pancreatic CD24 + adenocarcinoma tissues by immuno-laser capture microdissection and nano-LCMS/MS. J Proteome Res 12, 2791-2804.

Address correspondence to: Rémi Longuespée, PhD Mass Spectrometry Laboratory

GIGA-Research Department of Chemistry University of Liège 4000 Liège Belgium

E-mail: remi.longuespee@ulg.ac.be 